\title{
Social work with families at social risk promoting gender equality
}

\author{
J. Pivoriene and R. Bardauskiene \\ Mykolas Romeris University, Vilnius, Lithuania
}

\begin{abstract}
The article is based on the research whose aim is to find out the attitudes of social workers toward gender equality. The qualitative research was carried out in 2014 in order to find out social workers' attitudes to gender equality in families and families at social risk, as well as obstacles and possibilities for implementation of gender equality in families at social risk. Eight social workers working with families at social risk were interviewed using semi-structured interview and content analysis for research data analysis. The research data reveals that gender equality in the family can be reached by mutual agreement, when the division of duties and responsibilities is in accordance with needs and abilities of family members. Good family relations are emphasized as a prerequisite for gender equality. Families at social risk with unbalanced social functioning and relationships are affected by stereotyped thinking about gender roles. As informants point out, this makes gender equality impossible in families at social risk. Social workers reveal that they do not directly relate the gender dimension with social work practice, and as a result it becomes problematic to promote gender equality in families at social risk. The main obstacles for implementation of gender equality are clients' resistance to change, too much responsibilities put on women-mother by social workers and other institutions that deal with social risk families, lack of information on gender equality and tools for promoting gender equality in the family. However, the informants provide solutions for promotion of gender equality in micro, mezzo and macro practice that correspond to the guidelines presented in the documents and strategies on gender equality at national and EU level.
\end{abstract}

\section{Introduction}

Gender equality means equal rights, responsibilities and opportunities of women and men. Gender equality does not indicate that women and men will become the same. The aim is that a person's rights, responsibilities and opportunities will not depend on whether a person was born a male or a female. Gender equality means taking into account women's and men's interests, needs and priorities, recognizing the diversity of different female and male groups. Equality between women and men is not only innate human rights, but also a precondition for, and an indicator of sustainable people-cantered development (Gender Mainstreaming, 2001). Lithuanian legislation (eg., Law on Equal Opportunities (Official Gazette, 2003, no. 114-5115), National Programs of Equal Opportunities for Women and Men (Official Gazette., 2005, no. 116-4202) and 2010-2014 (Official Gazette., 2010, no. 56-2757)) ensure equal rights for men and women to participate in politics, at work and education, to engage in scientific activities, to receive equal services and handling of equal quality etc. However, gender equality is not just the same rights and obligations. This means that it will not become real if women and men will have different conditions and possibilities to 
implement existing rights. On the other hand, not all areas of human life are regulated by law. The division of responsibilities in the family, the approach to what is masculine and feminine determine different opportunities for women and men to participate in society, to achieve their objectives, to realize skills and ambitions, and exercise their existing rights. It conditions gender conflicts in public and private lives, deepens social exclusion and creates a background for discrimination.

The guidelines for gender equality implementation (Lyčiụ lygybès principo igyvendinimo..., 2005) determine the basic principles underlying the gender equality policy in Lithuania. The principle of equal division of authority and the power and influence means that women and men have to have equal representation in legislative and executive government, local councils and administrations, other state bodies, in the decision-making bodies of public organizations and private companies, as well as equal opportunities to participate in making important decisions. The principle of equal opportunities to be financially independent includes equal opportunities for men and women to have a job and get a personal income, equal work or work of equal value and receive equal pay. It is important for both genders to have equal conditions to seek education and career, to get equal social benefits, social or health services, which are available through paying state taxes dependent on a salary. The principle of sharing responsibility for family and children involve equal sharing of duties and responsibilities, protection of women and men from the violence based on a person's gender and gender discrimination.

Although public social relationships and family roles are changing, the patriarchal attitudes toward Lithuanian family remain fairly strong. The role of women in many families is treated traditionally as the mother, the guardian of the hearth and home, children's teacher and patroness (Burvytė, Ralys, 2012). Bučaitè-Vilkè (2012) argues that the asymmetry of roles in the family symbolizes well-established patterns of gender relations models and regulatory relations in society that are transferred to a private home sphere. The author also points out that the quality of family relationships, interactions of spouses or partners enhance the emotional closeness, reduce potential conflicts and encourage more equal division of roles in the family. Increased satisfaction with marriage or partnership is directly related to the woman-caregiver model transformation and becomes significantly greater condition for gender equality in the family.

Achieving gender equality in the family institute is a complex process and it becomes even more complex with the emergence of additional factors. Families at social risk face double stereotyping. They are affected by general attitude dominating in society to men and women, as well as by the image of family at social risk which maintains negative stereotypes. Social workers provide social services for families at social risk. Namely social workers are those who can contribute to the achievement of gender equality in families through prevention and intervention measures. S. Rutkauskienè, J. Gudliauskaitè-Godvadè (2011) see social workers as having the potential to promote positive changes achieving gender equality in the social services sector, improving the status of women in public and private life, reducing genderstereotyped attitudes to gender roles and ensuring fairness for women and men. But are social workers empowered as professionals to put their efforts to gender mainstreaming? Do social workers recognise their duty to promote gender equality in the family? Do they set such a goal in social work practice? Do social workers have enough knowledge, tools and willingness to put their efforts to gender mainstreaming? If we look at the latest Global definition of social work approved by the International Federation of Social Workers in $2014^{1}$ we cannot find principle of gender equality mentioned there. Of course, there are

${ }^{1}$ See http://ifsw.org/get-involved/global-definition-of-social-work/ 
very important principles such as social justice, human rights, collective responsibility and respect for diversities. We can just read between the lines and understand that gender equality is somewhere close to empowerment, liberation and human rights. The next important argument that insufficient attention is paid to gender equality in social work practice is the textbooks used for teaching social workers. For example, starting from older ones like M. Payne (1997), C. Zastrow (2003) or newer like F.C. Turner (2011) you cannot find much about gender equality there but mainly about feminist social work and women issues. Of course, it should be recognized that social work is a female profession and clients are mostly women as they suffer from violence, lower economic position, they have been bound by more social restrictions, have to deal with double burden reconciling work and family etc. But isn't it a discrimination against men, presenting them as alcoholics and abusers, who have higher status and income without mentioning problems of discrimination and violence against men? Isn't it a jug-handled presentation of gender issues when mostly women problems are highlighted through feminist theory and men problems are not analysed through masculine theories? We have to admit that gender equality is not only about women but also about men empowerment. The European Union acknowledges importance of both genders in promoting gender equality: "Gender equality needs to address both genders in order to sustainably change predominant gender imbalances and inequalities in European societies" (The Role of Men, 2012:2).

A scientific interest in gender issues is rising in Lithuania. Feminism and gender equality is analysed by J. Reingardienè (2004a, 2004b, 2004c, 2009), L. Šimanskienè (2006), V. Šidlauskienè (2011); gender discrimination is explored by S. Ustilaite (2007), L. Okunevičiūtè-Neverauskienè (2010), J. Vveinhard, P. Žukauskas (2012); development of the status of women and men as well as society's attitudes with respect to the genders and the attitudes of Lithuanians towards political participation of women is the focus of G. Purvaneckienè $(2004,2012)$; participation of women in science and carrier possibilities are analysed by R. Ališauskienė, G. Purvaneckienè (2009), A. Novelskaite, G. Purvaneckienė (2009). The leading researcher in masculinity issues is A. Tereškinas $(2004,2007,2008$, $2009,2011)$. However, there is a lack of researchers from social work field who would be interested in gender issues. R. Jančaitytė (2010), J. Gudliauskaitė (2008) and S. Rutkauskienė J. Gudliauskaitė-Godvadè (2011) can be listed among those few who analyse gender situation. Therefore, it is important to examine social work with families at social risk in a gender perspective. The coherence of social work and gender issues requires a lot more research and therefore the significance of the survey presented in the article is obvious.

The object of the research is the promotion of gender equality in social work with families at social risk. The aim of the paper is to identify social workers' approach to gender equality in social work with families at social risk. Research questions are as follows: what is social workers' approach to gender equality in family and family at social risk? What factors do disturb implementation of gender equality in family at social risk? What are the opportunities to promote gender equality? A qualitative research was carried out in spring 2014 using semi-structured interviews as a data collection method. The criterion sampling was used to select the informants that had to meet predetermined criterion: a professional (i.e., having a legally required education) social worker, working with families at social risk. A total number of 8 female social workers participated in this research. 3 informants have Master degree, 2 have Bachelor degree and 3 have completed their studies in colleges. The average age is 29 years and work experience with families at social risk varies from 1.5 years to 6 years. One informant works in a public organization, 2 work in non-governmental organizations and 5 in state institutions.

The interview data were analyzed using qualitative content analysis, which involves multiple text reading, segregation of categories based on keywords, division the categories 
content into subcategories, and interpretation of categories and sub-categories as well as justification with supporting statements from the text.

The study followed the basic principles of research ethics such as awareness, voluntary, and confidentiality. The research was carried out with the verbal permission of the authority of the informants. The quotation of informants in the article is presented precisely, without distortion and interpretations.

\section{Gender equality in the family and family at social risk}

One of the important aspects of gender equality is division of responsibility between spouses or partners in the family. Usually women are seen as those oppressed and facing double burden in reconciling work and family. The most attempts for seeking gender equality in the family are made to involve the man in housework and child care. According to the research data social workers believe that the duties (parenting and care, domestic work) in the family should be distributed equally: "The duties should be distributed equally, not that one carries all on his shoulders ... If a woman is cooking dinner, a man may do other tasks at home (2), ... Parenting is a matter of both parents, child rearing and participation in educational activities is a matter of both, and spouses participate equally (4), $<\ldots>$ many things then you need to share fifty-fifty, say housework can be shared, children accompany to and fro $\langle\ldots\rangle(6)$. J. Bučaitè-Vilkè (2012) argues that more equal roles in the family are promoted by the quality of family relationships. The informants noted that the impact of an intimate microclimate and good communication is very important for seeking gender equality in the family. Furthermore, mutual understanding that gender equality is a desirable thing in the family is essential: "Primarily, a man and a woman have to have the same understanding of what is gender equality because two people bring different values to the family (2)", "This is not only a matter of attitude but also a work, it does not happen by itself, it is necessary to invest, it is a quest for compromise and agreement that it would be better for both... (4)", "There should be respect in the family, understanding and tolerance. If there is understanding, and communication within the family $\langle\ldots\rangle$ it has to be from the beginning (5), “ $<\ldots>$ in the family there should be communication, understanding, one is responsible for one area, the other for different one (6).

Stereotypical roles in the family vanish if the responsibilities are divided with regard to personal skills and hobbies, because each family member assumes the duties and responsibilities according to their personal needs, abilities and individual situation. The agreement between a man and a women what is appropriate for both has also a fair importance: "Maybe then there is no roles in such a family where gender equality exists (1)", "I believe that the main point is that when there is gender equality, it looks like there is no division of roles, because then both persons are versatile and can do anything, even there can be the model, the man a breadwinner, while the woman is a housewife, if this is their agreement and in fact both feel that they want this (4), The division of labour is based on what a person is prone to, division according to what you like and under the agreement (4).

The informants emphasize that there is no gender equality in families at social risk. Uneven division of roles influenced by stereotyped thinking and the traditional approach to gender roles in the family reinforce inequality: "I think that there is such a traditional approach to gender roles in families at social risk (3)," $<\ldots>$ if taking families at social risk, my experience shows that typical stereotypes are very influential $\langle\ldots\rangle$. A family at social risk meets all the stereotypes that reinforce gender inequality. In that sense, whatever is opposite to gender equality in the family is strengthened and highlighted (4)". " <..> there is really no certain equality in the housework and child care in families at social risk $<\ldots>(6)$. 
Summarising the viewpoint of social workers about gender equality in families at social risk, it is important to notice that gender equality in the family can be reached by mutual agreement, when the division of duties and responsibilities is in accordance with needs and abilities. Good family relations are emphasized as a prerequisite for gender equality. Families at social risk with unbalanced social functioning and relationships are affected by stereotyped thinking about gender roles. As informants point out, this makes gender equality impossible in families at social risk.

\section{Problems of promoting gender equality in families at social risk}

Gender mainstreaming is considered to be a strategy for promoting gender equality, which indicates ensuring gender perspectives in all activities of social, political and economical life of society. The research data show that the informants do not see gender mainstreaming in social work practice: "Now you are asking me, and I start thinking, neither that gender equality is relevant to me, nor I do hear about it (2)", "It is an agreement question in each family, I cannot explain to the man that he must look after the children, perhaps he does not need it, and perhaps the woman does not need that either, as she feels comfortable (3)", "Ah, somehow I do not give prominence in social work, let say, I do not see there is any problem (7)”.

Moreover, the informants point out that they are not empowered to put their efforts to gender mainstreaming as they have no information and tools for promoting gender equality in the family: "For example, a social worker is offered a variety of courses on how to work with families at social risk, as well as with addicted persons, but nobody speaks about gender equality. There is not only the lack of information, but there is not information at all (2)", " $<\ldots>$ I would like to learn how to implement that gender equality, how to present that information to the people that they could realise the possibility to live on an equal basis. But not only just a theory, but also how to put it into practice, that is what I would like to know (8)".

The informants do not believe that it is possible to solve the problems of gender equality in families at social risk. They argue that it is a hard work, especially because of clients' strong resistance caused by the influence of gender socialization and stereotypes and therefore they feel helpless solving gender issues in the family: "You can't re-educate a person, you can try, but there will be a resistance (1)", "Because there is nurture and you are implanted with the information from an early age, the time when you accept information the most and you are told how you have to behave. So if I, as a social worker, come and say that you have to behave in such a way, nothing doing, I will be flipped out (3)" "It is very difficult here, if at all to seek for gender equality in the family, there should be changes of its approach, but we know what it means to change human attitudes, it is unrealistic (4)", “<..> but also all kind of defensive mechanism work, and maybe he will not agree with that, so what to do. They do not see this problem (6)". The informants also present the problem of shortage of time for dealing with gender issues in social work with families at social risk: "In fact, I think that we should almost live in this family not just to visit for two hours, if we want to change something (2)". This indicates that social workers do not have appropriate methods and tools how to promote gender equality in families at social risk and they need information and training on gender issues.

One more challenge highlighted by the informants is that social work practice mostly focuses on the mother-woman, her family responsibilities, and the father-husband is ignored in the process of solving social problems: "social work mainly focuses on a mother, a woman has to carry everything on her shoulders (2)", “<..> we demand too much from women, but men have also to be involved (6)". The informants point out the problems of oppressive 
state policy and practices expressed through the institutions that deal with families at social risk: " $<\ldots>$ I mean the police officers $\langle\ldots>$, no matter that the spouses are not divorced, but they live apart, more responsibilities are shouldered on a mother and she is fined for. For example, if the children live with the mother and father lives apart, I think, that both must be arraigned, and not just the mother (5)", " $<\ldots>$ in many places we emphasize mother, or parents in plural, or mom, a mother's and child's centre, because mother is seen everywhere (6)". It seems that the state controls women as wives and mothers much more than men, deepening existing inequalities in the private life.

The social worker's awareness on gender equality is also mentioned as one of the possible interference: "On the one hand our social workers, for me it is a tragedy. When asked, they follow the same stereotypes of what is boyish and what is womanish. The girl cannot run fast, 'why are you running like a boy?' Social workers are the same part of our society, living in the same stereotypes and they rely on the Patriarchate $\langle\ldots\rangle(4)$ ".

In summary, the opinion of social workers reveals that they do not relate the gender dimension with social work practice, and as a result it becomes problematic to promote gender equality in families at social risk. The main obstacles for implementation of gender equality are clients' resistance to change, too much responsibilities put on women-mother by social workers and other institutions that deal with social risk families, lack of information about gender equality and tools for promoting gender equality in the family.

\section{Opportunities for promotion of gender equality in a family at social risk}

Although the informants only relatively associate social work and gender issues, but they provide a number of possibilities for promoting gender equality in the family. Their proposals involve micro, mezzo and macro level interventions. The informants point out that promotion of gender equality should start from the assessment of the situation in the family at social risk: "So, from that it should be started, he must first assess what is the situation in the family, to capture what is going on in the family and what are roles there. The primary work is to assess the situation in the family and then make a plan of what needs to be changed (7)". The informants also note the need to promote the family division of labour, regardless of the prevailing society stereotypical attitudes about gender work specificity: " $<\ldots>$ enable a man and a woman, both to divide their duties in half $\langle\ldots\rangle$. I think it's very important (6)" $<\ldots>$ educating the family, that there is no male and female work, that they both can do equally. There is still prevailing attitude, that I will not do this, because it is a female work. Mainly a social worker can help by providing information and encouraging to do it $<\ldots>(8)$.

The research data shows a special attention of the informants to particular female and male problems in the family at social risk. In terms of women's situation in families at social risk, social workers' attention should be directed to the empowerment of women in the labour market, striving to be economically independent: " $<\ldots>$ within the family enabling women to be economically independent, that a woman should be in the labour market $<\ldots>$ (4)", "It may be women's empowerment through a financial, economic independence and employment. It is the empowerment of women, just the realization that you have power in your hands, something that you can control, and also to contribute to the family. And this is associated with self-esteem, women's self-esteem is a bit different (4)". Enabling participation of women in the labour market it is important to change women's attitudes, because in most cases women from families at social risk follow traditional roles: "I think maybe the women's attitudes need to be changed, because the women are used to be housewives (6)" Implementing gender equality in families at social risk man's position has also to be changed. 
It should be done through increasing male responsibilities in the family. A social worker should encourage men to participate more in child care and rearing as well as household activities: "If you work with the family, you try not only to stimulate mother's responsibilities, but also dad's (5)".

R. Jančaityte (2010) argues that it is a social worker who, working in mezzo and macro levels and striving for gender equality, has to propose projects, programs, and carry out educational activities aimed to eliminate negative gender stereotypes, analyze and evaluate implementation of equal opportunities in public and private areas, providing proposals to the authorities. The informants have also suggestions for intervention in mezzo and macro levels. Spread of information about the gender issues is one of the tools for gender mainstreaming. The informants note that society should be enlightened on gender equality through the media, on television, through social advertising, and public debate. A greater attention should be paid to rural areas where access of information is noticeably limited. Dissemination of information must be simple and understandable to ordinary members of society: “. . I would like that it would be spoken loudly about that, the society should be more educated through the media, $T V$ and advertisements on the stands (1)", "<..> it is necessury to talk more about it, to provide information so that more people could feel orientated (2)", “< . > it is necessary to educate society through the media, on TV, but somehow interesting, because if you just write an article nobody will read it (2)", "I think it should be disseminated in society so that people could be aware of this issue. It should be more emphasized and talked in the media (5)," $<\ldots>$ if such a project has to be implemented, it should be started from the outlying regions and form practical advice, rather than just a theory, which is not interesting and difficult to realize (8).

The spread of information about gender equality should start from the early age, because as A. Tereškinas (2011) points out, a person learns roles through relationship with social structures like family, or educational institutions. The informants emphasise the need to pay more attention to the child and his/her development. " $<\ldots>$ It should start from primary school, kindergarten, school (1)" "Then you have to start with children doing small steps in the sense of the simplest little things. When speaking about all sorts of children activities and circles, it should be emphasized that if a girl wants to go to attend some kind of constructors course, this is $O K$, as well as the boy wants to attend ballet. In those families there is a very clear division of roles - the boys go to play football or basketball and the girls go dancing or to a knitting circle. In this sense if the child has a bent for something it is necessary to encourage whatever bent it is. It is necessary to start emphasize all the talents of the child, regardless of what is appropriate for gender according to societal stereotypes (4)", < . > it should be started from an early age (4).

The collaboration of different institutions and professionals is also important for gender mainstreaming. Representatives of different institutions that have direct contact with families or working in a team with social workers can reach a common goal promoting gender equality in the family: police officers are those who explain them that they may be punished as there is written in the law and the Family Code that both parents must take care of and to be interested in the child, his education and material well-being. Both parents must participate, in accordance with their possibilities (5), “< . > it could do social workers, representatives of neighbourhoods, as they interact much with their people, communities are very active at the moment, I think that also communities can spread these issues (8)".

In summary it can be said that the informants do not directly link social work practice with promotion of gender equality. However, they provide solutions for micro, mezzo and macro practice. In micro level of social work practice the promotion of gender equality should start from the assessment of the situation in the family at social risk and planning the intervention, education of the family how to divide housework equally, empowerment of women to 
be economically independent as well as increase of men responsibilities in the family. Mezzo and macro level interventions include spread of simple and understandable information about the gender issues to ordinary members of society and especially education of children about gender equality. The collaboration of different institutions and professionals is also important for gender mainstreaming.

\section{Conclusions}

Equality between women and men is not just human rights, but an important precondition for and an indicator of sustainable people-cantered development. It must be recognised that both women and men have different social problems or experience them differently and therefore both genders need a gender specific concern and services.

There is a noticeable shortage of gender mainstreaming in social work practice. Significant endeavour of feminist theorists has raised women problems putting them on social work agenda while men issues have been left behind. Therefore there is an asymmetry in promoting gender equality as it is seen mostly from women perspective. Apart from that, promotion of gender equality is not seen as an important goal for social work practice because it is not mentioned in the global definition of social work or analysed much in social work textbooks.

The research data reveals that social workers believe in the importance of family duties to be distributed equally under the agreement between a man and a woman on what is appropriate for both. The quality of family relationships and mutual understanding that gender equality is a desirable thing in the family are also essential.

The data shows that the informants do not relate the gender dimension with social work practice, and as a result it becomes problematic to promote gender equality in families at social risk. Families at social risk experience double stereotyping as families with multiple social problems and those with traditional gender roles. Social workers feel helpless solving gender issues in the family at social risk because of clients' strong resistance. Too much responsibility is put on women-mothers by social workers and other institutions that deal with families at social risk, making promotion of gender equality a hard work. The informants also point out that they are not empowered to put their efforts to gender mainstreaming as they have no information about gender equality and measures for promoting gender equality in the family.

The proposals of social workers on how to promote gender equality in families at social risk are more on theoretical level. Their suggestions concern micro level interventions, such as assessment of situation, equal distribution of responsibilities in the family, empowerment of women to be economically independent and involvement of man in child care and housework. On mezzo and macro levels they propose spread of information about the gender issues and adding specific topics to the educational programs of children. The collaboration of different institutions and professionals in promotion of gender equality is also seen as important. But social workers have no measures how to implement these theoretical issues into social work practice.

\section{References}

[1] R. Ališauskienè, G. Purvaneckienè, Moterys politikoje: ar sulauksime padaugèjimo? Lyčių studijos ir tyrimai. Šiaulių universitetas. Šiauliai, Šiaulių universiteto leidykla Nr. 7 (2009).

[2] J. Bučaitè-Vilkè, Šeimos tarpusavio santykiu kokybe ir prokreaciniai ketinimai, Lyčiu politika ir gimstamumo ateitis. Monografija. Kaunas: Vytauto Didžiojo universiteto leidykla, p. 153-175 (2012). 
[3] S. Burvytè, K. Ralys, Ugdytoju vaidmenys ir ju lygiateisiškumas. Ugdymo šiuolaikineje šeimoje konceptas. Mokslo studija. Vilnius: Edukologija, p. 26-43 (2012).

[4] Gender Mainstreaming: Strategy For Promoting Gender Equality (2001). Access from the Office of the Special Advisor on Gender Issues and Advancement of Women http://www . un.org/womenwatch/osagi/pdf/factsheet1.pdf (2015, May 24).

[5] J. Gudliauskaitè, Lyčiu aspekto integravimas socialiniame darbe. Socialinis darbas. Patirtis ir metodai. Kaunas: Vytauto Didžiojo universiteto leidykla, 1(1), p. 21-33 (2008).

[6] R. Jančaitytė, Požiūriai i problemu sprendima socialiniame darbe, In J. Šimkūnienė (Ed.). Socialinis darbas, profesinė veikla, metodai ir klientai. Vadovèlis. Vilnius: Mykolo Romerio universiteto Leidybos centras, p. 72-103 (2010).

[7] Lyčiụ lygybės principo iggyvendinimo gairès Lietuvos savivaldybėms (2005). Vilnius: Petro ofsetas.

[8] A. Novelskaitè, G. Purvaneckienè, Moteru ir vyru moksliniu karjeru tendencijos Lietuvoje ir Suomijoje. Acta paedagogica Vilnensia. T. 22 (2009).

[9] L. Okunevičiūtè-Neverauskienè, Teisiniu politiniu dokumentu, reglamentuojančiu antidiskriminacine politikq sqvadas. Mokslo studija. Vilnius: Eugrimas (2010).

[10] M. Payne, Modern social work theory. Consultant ed. J. Campling. Hampshire: Macmillan (1997).

[11] G. Purvaneckiene, Gender dimension in the process of social change. Socialiniai mokslai Nr. 1 (43) (2004).

[12] G. Purvaneckienè, Lyčiu lygybès politikos būklè Lietuvoje. Viešoji politika lyčiụ lygybės aspektu: teminis straipsnių rinkinys. Vilnius, Mykolo Romerio universitetas (2005).

[13] Giedrè Purvaneckienè, Mokslininkiu karjera tiksliuosiuose moksluose ir šeima: pasirinkimas ar dermé? Acta paedagogica Vilnensia, t. 21 (2008).

[14] J. Reingardienè, Lyčiu santykiai, Sociologija: vadovèlis aukštụjų mokyklų studentams. Kaunas: Vytauto Didžiojo universiteto leidykla, p. 119-133 (2004 a).

[15] J. Reingardienė, Europos lyčiu lygybès strategija: kintančios lyčiu politikos privalumai ir grèsmès, Sociologija. Mintis ir veiksmas, Nr. 3 (teminis numeris), p. 13-26 (2004 b).

[16] J. Reingardienè, Lyčiu lygybès strategija ir užimtumo politika Europos Sajungoje. Mokomoji knyga. Kaunas: Vytauto Didžiojo universiteto leidykla (2004 c).

[17] J. Reingarde, Socialinès ir kultūrinès lyties formavimas, In Lytiškumas, socialiniai kultūriniai ir sveikatos aspektai: straipsnių rinkinys. Vilnius: Senoja (2009).

[18] S. Rutkauskienè, J. Gudliauskaitè-Godvadè, Lyčiu stereotipai socialiniame darbe su socialinès rizikos šeimomis, Socialinis darbas. Patirtis ir metodai, 7(1), p. 71-87 (2011).

[19] V. Šidlauskienè, Lytis ir lyčiu lygybès politika švietime: i lytiškumo ugdyma(si) orientuotu modeliu konstravimas institucijose. Mokslo darbų apžvalga. Šiauliai: Šiaulių universiteto leidykla (2011).

[20] A.Tereškinas, Tarp norminio ir subordinuoto vyriškumo formụ : vyrai, jụ seksualumas ir maskulinizmo politika šiuolaikineje Lietuvoje. Sociologija. Mintis ir veiksmas Nr. 3 (14) 2004.

[21] Tereškinas, Who's afraid of men? Researching men and teaching masculinity studies, Socialiniai mokslai Nr. 1 (55) (2007).

[22] Tereškinas, Kas bijo vyru? Maskulinizmo studijos pokomunistinèje Lietuvoje. Inter-studia humanitatis Nr. 5 (2008).

[23] Tereškinas, Social suffering, post-soviet masculinities and working-class men. Socialiniai mokslai Nr. 2 (64) (2009). 
[24] Tereškinas, Vyrụ pasaulis: vyrai ir žaizdos vyriškumas Lietuvoje. Vilnius: Baltos lankos (2011).

[25] The Role of Men in Gender Equality - European strategies \& insights Study on the Role of Men in Gender Equality Contract ref. no. VC/2010/0592 December 2012. Edited by Elli Scambor, Katarzyna Wojnicka \& Nadja Bergmann (2015).

[26] F.J. Turner (ed.), Social work treatment: interlocking theoretical approaches. Oxford, New York (NY): Oxford University Press (2011).

[27] S. Ustilaitè, Lyčiu diskriminacija ir prielaidos jai atsirasti. Vaikų ir jaunimo rengimo šeimai programụ rengimas: mokomoji ir metodinè priemonè. Vilnius: Sapnụ sala, p. 9-10 (2007).

[28] J. Vveinhardt, P. Žukauskas, Mobingas darbuotoju santykiuose. Individas. Organizacija. Sociumas. Monografija. Kaunas: Vytauto Didžiojo universiteto leidykla (2012).

[29] C. Zastrow, The practice of social work: applications of generalist and advanced content. Pacific Grove (Calif.): Thomson Brooks/Cole (2003). 